Arab World English Journal (AWEJ) Volume 12. Number1 March 2021

DOI: https://dx.doi.org/10.24093/awej/vol12no1.23

Pp. 339- 356

\title{
Investigating Saudi EFL Students' Knowledge and Beliefs Related to English Reading Comprehension
}

\author{
Saud Alenezi \\ Department of Languages and Translation \\ Faculty of Education and Arts \\ Northern Border University, Arar, KSA \\ Email: Saud.alenezi@nbu.edu.sa
}

Received: $10 / 17 / 2020$

Accepted: 2/20/2021

Published: 3/24/2021

\begin{abstract}
Reading is an essential strategic and a life-long skill required for success in learning. The current study explores the knowledge and beliefs of Saudi students of English as a foreign language (EFL) about English reading comprehension strategies. It also intends to determine if there is a significant correlation between the students' foundational knowledge of English reading comprehension strategies and their beliefs about reading comprehension strategies. The study employed a quantitative method. The data were collected using a forty-item survey questionnaire. The respondents were 203 Saudi EFL students enrolled in Preparatory Year Program at Northern Border University in Saudi Arabia. The data collected were analyzed using descriptive statistics to determine frequency, percentage, mean, standard deviation, and a test of non-parametric correlation (Spearman's rho correlation coefficient) was run to determine the relationship between the variables. The overall findings of the study revealed that the students have a good foundational knowledge of pre-reading, while-reading, and post-reading reading strategies. The correlational analysis showed a medium correlation between students' foundational knowledge of reading strategies and their beliefs about reading strategies. In conclusion, the study suggests some implications for teaching English reading to EFL students.
\end{abstract}

Keywords: Extensive reading, foundational knowledge, foreign language learning, intensive reading, reading comprehension, reading strategies, Saudi EFL students, students' beliefs about reading strategies

Cite as: Saud Alenezi, S. (2021). Investigating Saudi EFL Students' Knowledge and Beliefs Related to English Reading Comprehension. Arab World English Journal, 12 (1) 339- 356. DOI: https://dx.doi.org/10.24093/awej/vol12no1.23 


\section{Introduction}

Language learning strategies are essential aspects in language learning. The foundational knowledge of effective learning strategies helps language learners to become self-managed and self-regulated learners who take responsibility for their education (Habok \& Magyar, 2018). Reading is an essential strategic and a life-long skill required to achieve higher academic performances (Shoebottom, 2015). In other words, reading is a substantial skill that contributes to success of learners of foreign language learning. Recent educational trends consider reading as the prerequisite skill required at the beginning of cognitive growth and attaining the necessary skills of language (Alshumaimeri, 2017; Wang, 2017).

Moreover, several studies conducted by researchers about English reading strategies and acquisition in foreign language contents have attempted to look for components that affect students' reading performances, and teaching methods. Concerning students' knowledge, some students struggle to read just a few words appropriately, while at the same time, others can read fluently. Students mostly encounter problems while reading, for example, lack of self-study activities, spelling and pronunciation problems, disinterest in collaborative work, and difficulties to apply scanning and skimming reading strategies (Nezami, 2012).

Moreover, the Saudi Ministry of Higher Education has prioritized the teaching of the four basic skills of language (reading, writing, listening, and speaking) at Preparatory Year Program (Mitchell \& Alfuraih, 2017). It set a standard English course curriculum in a way that supports a learner-centered approach and peer collaboration. However, Saud EFL students are facing some challenges in adopting to the new standard. Generally speaking, the Arab countries reported some common problems including, poor foundational knowledge, poor reading habits, and students' attitudes regarding reading in English (Almahrooqi \& Denman, 2016). As gaps in the literature, the researcher noticed that, although there are several studies conducted in the foreign language context about the issues of English reading skills, mostly the researchers have focused on measuring reading strategies and the students' performances in reading comprehension (AlQahtani, 2016; Al-Jahwari \& Al-Humaidi, 2015; Bakhshalinezhad, Nikou \& Bonyadi, 2015; Fitrisia, Tan \& Yusuf., 2015; Han \& Choi, 2018; Rajab \& Al-Sadi, 2015). Few studies have investigated the foundational knowledge and beliefs of teachers about reading strategies (Al Asmari \& Javid, 2018). The researcher noticed the need to conduct similar study to investigate the students' foundational knowledge and their beliefs regarding reading strategies. Henceforth, the current study is an attempt to examine Saudi EFL students' knowledge and beliefs related to English reading comprehension strategies.

This study is essential as it extends the understanding of reading comprehension from the students' accounts on their beliefs and perceptions of academic reading and reading strategy usage. Also understanding the students' knowledge and expectations is a prerequisite to meet language course objectives.

\section{Questions of the Study}

1. What are the levels of foundational knowledge of English reading comprehension strategies and beliefs of Saudi EFL students in the Preparatory Year studies at Northern Border University? 
2. Is there a significant correlation between Saudi EFL students' foundational knowledge of English reading comprehension strategies and their beliefs about reading comprehension strategies?

\section{Literature Review}

Major linguistics theorists such as Piaget (1976), Vygotsky (1978), and Chomsky (1986) have considered reading as a process beyond more than just seeing and pronouncing words or attaining the aspects of phonology and semantics. However, reading is not merely decoding the written material of language; instead, it involves how we interact with the whole language through critical thinking, understanding contexts, and meanings (Crossley, Kyle \& McNamara, 2016). In the past, there are two main models of teaching reading comprehension, namely, bottom-up and top-up models. The bottom-up model regarded reading development as a textdriven method where merely the text holds the significance irrespective of the reader's understanding, while the top-down model is a reader-driven procedure with text reading belonging to the eye of the reader. Later the third reading model emerged, which is called an interactive method. According to this model, understanding a text involved diverse reading processes, including the reader, the text and the context (Horiba \& Fukaya, 2015). There are two types of communication while reading. First, it refers to the reader's use of both bottom-up (lower-level) and top-down (higher-level) processes. Second, it denotes the communication between the reader and the text while triggering the readers' schema and background knowledge (Hudson, 2007).

Okasha (2020) examined the effectiveness of using strategic reading techniques for improving EFL reading skills among Saudi university students. The experimental group used strategic reading techniques, while the control group received traditional class method. Study results showed that Saudi EFL learners need an innovative strategy to help them improve their reading. Therefore, the researcher recommended that teachers should adopt new techniques for providing feedback to EFL learners in reading, such as peer-review, reading conferences, and self-correction.

Taladngoen, Palawatwichai, Estaban, and Phuphawan (2020) explored factors affecting Thai EFL tertiary students' reading comprehension ability. Study participants were 19 EFL tertiary students majoring in English for International Communication (EIC) in the Faculty of Business Administration and Liberal Arts at Rajamangala University of Technology Lanna Phitsanulok. The data were collected using a questionnaire and analyzed using descriptive statistics. The findings showed the participants' linguistic knowledge impacted on their reading comprehension ability than their perceptions. On the other hand, their background knowledge of the reading content was the most affecting sub-internal factor, at the same time, their perception of reading difficulty was the least affecting sub-internal factor.

The study by Alenizi (2019) evaluated pre-university educators' beliefs about reading comprehension in English as a foreign language (EFL) in the framework of the Kingdom of Saudi Arabia. It also recognized the complications confronted by undergraduate students in their reading comprehension courses to have a rounded view of the education progression. The findings revealed that teachers' reluctance to awareness of teaching strategies causes adverse 
effects on the learners. The results also showed that the culture and background knowledge played substantial roles in enhancing students reading comprehension.

The study by Han and Choi (2018) examined Korean EFL middle school students reading performance. The study adopted a quasi-experimental design. The participants of the study were divided into experimental and control groups. Both groups received the same reading materials to read. However, participants in the control group answered comprehension questions only, in contrast, their counterparts in the experimental group received supplemented questions in three forms: literal, inferential, and evaluative. The results revealed a positive effect between postreading question-generation activities and cooperative learning on English reading abilities. The results also found the experimental group performed better than the control group regarding inferential and evaluative questions. On the other hand, self-learning was more operational than cooperative learning in the evaluative questions.

Haryanto, Mukminin, Habibi, Sulistiyo, and Peni (2016) conducted a qualitative study to explore information about the reading comprehension strategies employed by EFL students. The data was collected using an in-depth semi-structured interview. The study assessed the students' cognitive and metacognitive strategy under three phases: pre-reading, while-reading, and postreading. The findings of this study revealed that the participants employed some metacognitive strategies during pre-reading activities, such as: understanding the theme or heading of the text, observing the images, diagrams, maps, and other symbols, and reading the opening sentences. While reading a cognitive strategy was frequently engaged with reading to enhance comprehension and taking notes or highlighting vital material in a text. Further, during postreading, a cognitive strategy was applied to check or assess comprehension.

Torres (2017) conducted a study to investigate the influence of pre-reading exercises and summaries on EFL students' reading comprehension. The results showed that the learners can understand the key concepts of the texts. The findings also showed that students have opposing opinions on the effectiveness of both approaches for reading English texts before and after the intervention.

Al Asmari and Javid (2018) investigated the English language teachers' perception of Saudi EFL students' reading comprehension and the importance of content schemata in learning. This study explored the practical classroom approaches employed by English language teachers that enable content schemas and can improve the students' reading comprehension. Study results found students' reading problems are as result of a lack of suitable instructional materials needed by the students to activate the content schemata.

Rajab and Al-Sadi (2015) investigated the attitudes and preferences of EFL learners regrading personal practices of the reading skill in the first and second language. A ten-item questionnaire was used to gain insights into the attitudes of EFL students towards English reading comprehension. The results showed the participants lack interest and motivation in academic reading, in both the first and second language.

Qrqez and Ab Rashid (2017) investigated the reading comprehension difficulties faced by Jordanian EFL students. A questionnaire was used to collect the data from 200 students at 
Yarmouk University. The results of the study showed that the students had positive motivation towards English reading. However, the subjects faced some problems in the reading process, for example, unfamiliar vocabulary, ambiguous words, and limited available time to cognitively process the text.

Shehzad, Lashari, Lashari, and Hasan (2020) conducted a correlational study to find the relationship between Saudi learners' sources of reading self-efficacy beliefs and reading strategies. The study participants were 188 Saudi EFL learners selected using stratified random sampling from five public universities in Saudi Arabia. A questionnaire instrument consisting of three constructs, sources of reading self-efficacy, reading self-efficacy beliefs, and reading strategies, were used to collect the data. The results showed self-efficacy sources were substantially related to the reading of beliefs in self-efficacy. Reading beliefs in self-efficacy were also strongly associated with metacognitive reading strategies. On the other hand, the result showed that reading self-efficacy beliefs are positively and substantially associated with reading strategy.

Ahmadian and Pasand (2017) investigated the relationship between Iranian EFL students' usage of reading metacognitive strategy online and their self-efficacy in reading comprehension. The study further examined if there was an effect of gender in that respect. The data were collected from 63 Iranian EFL students using an online survey questionnaire instrument. The Friedman test results showed that online metacognitive reading strategies for problem-solving are most frequently used by learners, whereas support strategies are less regularly used. Furthermore, the results of MANOVA showed a substantial positive relationship between the perceived usage of metacognitive online reading strategies by learners and their self-efficacy in understanding reading. The study further revealed that women use more global strategies for online reading, while men were more self-efficient in reading online texts.

Kim (2016) examined the relationships between Korean undergraduate students' reading attitude and reading strategy. The data were collected using a questionnaire instrument distributed to153 Korean undergraduate EFL students. Descriptive analysis and ANOVA were used to analyze the data. The findings revealed that out of the six components used to test students' reading attitudes, only discomfort was linked to reading skills.

\section{Methodology}

In this current study, the researcher employed a quantitative approach to collect and analyze the data. According to Creswell and Plano (2012), there are three main designs in conducting quantitative research, experimental, correlational, and survey designs. The current study employs a descriptive survey. A correlation was used to find the relationship between the constructs on the survey.

\section{Setting and Participants}

The present study was conducted at Northern Border University, Arar, Saudi Arabia. The research respondents were 203 students enrolled in the Preparatory Year Program in the first semester of 2019-2020. Samples consist of male and female students selected using simple random sampling. Table one depicts the students' gender and age distributions. 
Arab World English Journal (AWEJ) Volume 12. Number 1. March 2021

Investigating Saudi EFL Students' Knowledge and Beliefs

Alenezi

Table 1. Students' gender and age distributions

\begin{tabular}{|c|c|}
\hline \multicolumn{3}{|c|}{ Gender Distribution } \\
\hline Male & Female \\
\hline $105(51.7 \%)$ & $98(48.3 \%)$ \\
\hline \multicolumn{2}{|c|}{ Age Distribution } \\
\hline $18-21$ & 22 and above \\
\hline $195(96 \%)$ & $8(4 \%)$ \\
\hline
\end{tabular}

\section{Data Collection}

Data collection is an essential part of any academic research. The instrument of collecting data is a tool for measuring, observing, or documenting quantitative data. It involves the instrument used to collect the relevant data to provide answers to the research questions. In quantitative data collection, a researcher uses a questionnaire to collect the quantitative data. A survey questionnaire designed by the teacher was the primary source of data collection in this study.

\section{Designing of the Survey}

This study employed a structured closed-ended questionnaire to collect the data. It contained a part for demographic information which asked about the students' age and gender, and it was followed by the main sections of the questionnaire. The questionnaire consisted of forty-item closed-ended questions divided into four sections under four constructs (i.e., prereading strategies, while reading strategies, post-reading strategies, and students' beliefs about English reading strategies). The first three sections (A, B \& C) contained 30 questions regarding students' foundational knowledge of English reading strategies. Section A contained a list of ten items about pre-reading strategies/activities. Section B contained ten items about while-reading strategies/activities. Section C contained ten items about post-reading strategies/activities. Section D contained ten items about students' beliefs about English reading strategies. This survey questionnaire was designed based on a five-point Likert-type. Moreover, the first thirty items of the questionnaire were rated using frequency as follow: $1=$ always, $2=$ often, $3=$ sometimes, $4=$ rarely, and $5=$ never. Meanwhile, the last ten (10) items were rated using degree of agreement: 1 = strongly agree (SA), 2 = agree (A), $3=$ undecided (U), $4=$ disagree (D), and 5 $=$ strongly disagree $(\mathrm{SD})$. The researcher used numerical values $(1,2,3,4, \& 5)$ to each item for easy access.

\section{Reliability and Validity of the Survey Questionnaire}

The researcher sent the developed survey questionnaire to three lecturers of English linguistics to check the content and construct validity of the survey questionnaire. Also, the questionnaire was pilot tested to check reliability using test/retest reliability with 100 students. A copy of the survey questionnaire was given to the students two times in a two-week interval. The overall internal consistency reliability of this survey questionnaire was $(\alpha=.93)(n=100)$. This result indicated that the instrument was reliable and ready to be used for data collection. 
Arab World English Journal (AWEJ) Volume 12. Number 1. March 2021

Investigating Saudi EFL Students' Knowledge and Beliefs

Alenezi

Table 2. Cronbach's Alpha Results for Reliability

\begin{tabular}{|c|c|c|c|c|}
\hline Constructs & Sections & Items & $\begin{array}{l}\text { 1st. Reliability } \\
\left(\alpha^{*}\right)\end{array}$ & $\begin{array}{l}\text { 2nd. Reliability } \\
\qquad\left(\alpha^{*}\right)\end{array}$ \\
\hline Pre-Reading Strategies & $\mathrm{A}$ & $\begin{array}{c}1,2,3,4,5,6 \\
7,8,9,10\end{array}$ & .95 & .93 \\
\hline $\begin{array}{c}\text { While Reading } \\
\text { Strategies }\end{array}$ & $\mathrm{B}$ & $\begin{array}{c}11,12,13,14 \\
15,16,17,18 \\
19,20\end{array}$ & .91 & .94 \\
\hline $\begin{array}{c}\text { Post-Reading } \\
\text { Strategies }\end{array}$ & $\mathrm{C}$ & $\begin{array}{c}21,22,23,24, \\
25,26,27,28, \\
29,30\end{array}$ & .93 & .94 \\
\hline $\begin{array}{c}\text { Students' Beliefs } \\
\text { about English Reading } \\
\text { Strategies }\end{array}$ & $\mathrm{D}$ & $\begin{array}{c}31,32,33,34, \\
35,36,37,38, \\
39,40\end{array}$ & .89 & .92 \\
\hline
\end{tabular}

*Cronbach's alpha $(\alpha)$

Table two illustrates the test-retest results obtained based on the four constructs of the survey questionnaire.

\section{Data Analysis}

Descriptive statistics (such as frequency, percentage, mean and standard deviation, and percentage) were used to analyze the data collected from the 203 students. A correlational test was further run to check if there was a significant relationship between the students' foundational knowledge of English reading strategies and their beliefs about reading strategies. All of these analyses run using Statistical Package for Social Science (SPSS) version 25.

\section{Results}

The study employed descriptive statistics to determine the frequency, percentage, mean, and standard deviation from the students' responses based on the four constructs divided into sections, A, B, C, and D, on the survey questionnaire to answer the first research question. What are the levels of foundational knowledge of English reading comprehension strategies and beliefs of Saudi EFL students in the Preparatory Year Studies at Northern Border University?

The results presented in Table three in appendix A show the students' perceptions of foundational knowledge of pre-reading strategies. The results indicate that the respondents perceived that they have good utilization of pre-reading strategies. Item 10 was the highest-rated under this construct with a very high mean score of 4.43 . It shows that 49.26 percent of the respondents are mostly discussing the topic of reading comprehension with their coursemates. It was followed by Items 5, 2, 9, 8, 1, 3, 4, and 7. Item five indicates that 49.26 percent of the respondents, with a very high mean score of 4.24 , are making predictions about the possible content of the text in a general way before they start reading. In Item two, 28.08 percent of the respondents with a very high mean score of 4.08 claimed that they often pay attention to the titles and subtitles before reading. Concerning the vocabulary, the result of Item nine shows that 67.99 percent of the respondents with a high mean score of 3.84, are often think about the possible 
vocabulary to be found in a given text before they start reading. Item eight indicates a high mean score of 3.77, with 38.92 percent of the respondents claimed that they are familiar with the process of watching videos about the topic of the text to activate schema (in texts accompanied with videos).

Concerning planning before reading, the result of Item one shows that 48.3 percent of the respondents, with a high mean score of 3.58 , claimed that they often plan what to do before reading the text. Item three indicates 42.36 percent of the respondents with a mean score of 3.57 are often focus on the words from the title. Subsequently, Items four and six have the same mean score of 3.39 and 36.45 percentage. They indicate that the respondents often engage in brainstorming for the possible topics in the text and predict the text of a given reading comprehension activity. The least-rated was Items seven with a medium mean score of 3.26, whereas 40.39 percent of the respondents perceived that they often predict about the content of the text from the pictures.

Furthermore, the results presented in Table four in Appendix B show students' perceptions about foundational knowledge of reading comprehension strategies they utilized while reading. The second ten items of the questionnaire asked students about the list of some activities they do or strategies they employ while reading comprehension. The results indicate that rates of the students' responses about 'while reading strategies' in the following order: 17 , $20,18,15,13,19,11,14,12$, and 16 .

Looking at the mean scores of these ten items under this construct (section B), items 17 and 20 are the highest-rated items. As shown in Table four, Item 17 has a very high mean score of 4.55, and Item 20 has a high mean score of 4.36. Moreover, Item 17 indicates that 61.084 percent of the respondents are always using a dictionary or Google translator to find the meaning of unknown words 'while reading'. Besides, Item 20 indicates that 46.798 percent of the respondents are always employing scanning strategies to understand the specific idea in the text 'while reading'. Item 18 has a high mean score of 4.29, which indicates 51.232 percent of the respondents often use knowledge of English grammar to help them in understanding the text 'while reading'. The next high-rated was Item 15 with a high mean score of 4.19 , which shows that 52.709 of the respondents often skip unknown words 'while reading' comprehension. It was followed by Item 13, which has a high mean score of 4.09, which indicates that 58.128 of the respondents often use to pay attention to the type of text when reading (like narrative, expository, scientific, or reference, etc.). The next was Item 19, which has a high mean score of 4.03, which indicates that most of the respondents $(76.847 \%)$ often utilize a skimming strategy for them to understand the main idea. Concerning to the topic sentence identification, the result of Item 11 shows that most of the respondents $(56.158 \%)$, with a high mean score of 3.95 , often try to understand the topic sentence in a paragraph 'while reading' comprehension. The subsequent high-rated was Item 14 with a high mean score of 4.03, which indicates that 41.379 percent of the respondents often use guessing strategy to understand the meaning of unknown words from the text. The next was Item 12 with a medium mean score of 3.30, which shows that 30.542 of the respondents often pay attention to punctuations while reading comprehension. Item 16 was least-rated with a medium mean score of (2.78) which indicates that 40.394 percent of the respondents claimed that they sometimes stop while reading to check the meaning of unknown words they found in the text. 
On the other hand, the results presented in Table five in Appendix $\mathrm{C}$ indicate the students' perceptions about foundational knowledge of post-reading strategies. The third ten items of the questionnaire asked students about the list of some activities they do or strategies they employ in post-reading comprehension. The results indicate the rates of students' responses about strategies they used while reading in the following order: 27, 24, 21, 23, 28, 29, 22, 25, 26, and 30 .

Item 27 was the highest-rated under this construct with a mean score of 4.56, which indicates that most of the respondents $(58.620 \%)$ discuss the read text with their coursemates. The next high-rated was Item 24, with a high mean score of 4.34, which indicates that 56.650 percent of the respondents perceived to have confidence in answering the reading comprehension questions. Concerning rereading, Item 21 with a high mean score of 4.15 shows that the most of the respondents $(55.665 \%)$ re-reading the text more than one time to get the main idea of the text.

Regarding evaluating excise, the result of Item 23, with a high mean score of 3.96, shows that 61.084 percent of the respondents often evaluate their reading plans to check whether they achieve their set reading purposes or not. Besides, this finding shows that about half of the students perceived to have an excellent self-evaluating strategy. The next high-rated was Item 28 with a high mean score of 3.96, which indicates that 35.961 percent of the respondents often collaborate with others (such as tutors, brothers, sisters, or parents) at home and discuss their reading comprehension activities. The next high-rated item was Item 29 with a high mean score of 3.58, which indicates that most respondents (64.039) often try to understand the text alone without peer collaboration or teachers' explanation. The next was Item 22, which has a high mean score of 3.57, with 40.394 percent of the respondents perceived that they often make notes for the main points in the text. The next high-rated was Item 25, with a medium mean score of 3.48 , which indicates that 38.916 percent of the respondents sometimes summarize the text in one's own words. Item 26, with a medium mean score of 3.11 , indicates that 56.158 percent of the respondents sometimes engage in making inferences from the text to understand the hidden meanings. Item 30 was the least-rated, with a medium mean score of 2.59 , which indicates that 34.975 percent of the respondents are sometimes used to read other materials (books, articles, etc.) related to the text to help in understanding the text.

Henceforth, the results in Table six, in Appendix D display the results of students' general beliefs about reading strategies. The responses of the participants are arranged in the following descending order based on their mean scores $(31,37,38,35,32,39,36,40,34$, and $33)$.

Item 31 was the highest-rated item with a very high mean score of 4.64, which indicates that the most of the respondents $(64.532 \%)$ strongly agree that language learning involves culture, so it is crucial to increase Saudi learners' cultural awareness of English speakers. Moreover, the result reveals that students firmly perceived the importance of selected the relevant reading comprehension texts based on their culture. The next high-rated was Item 37, with a very high mean score of 4.57, which indicates that most of the respondents (61.084\%) strongly agree that the focus in English reading classes should be more on the meaning than the rules of grammar. 
Regarding intensive reading, the result of Item 38 shows that 54.187 percent of the respondents with a very high mean score of 4.51 strongly agree that students should read intensively. Item 35 shows that 52.709 percent of the respondents, with a mean score of 4.42 , firmly believed that English reading classes should emphasize the students' ability to guess the meaning of unknown words from the context. Item 32 and Item 39 have the same mean score of 4.13. Meanwhile, Item 32 indicates that 45.320 percent of the respondents have a quite positive beliefs about extensive reading, and they acknowledged the importance of reading additional relevant materials at home and school. In addition to that, Item 39 shows that 66.995 percent of the respondents agreed that reading additional English materials such as newspapers, magazines, and books in addition to course material is a prerequisite for the students. This finding shows the students' have a positive belief about extensive reading.

Item 36, with a medium mean score of 3.32, indicates that 53.202 percent of the respondents are undecided about the reading between the lines technique to find hidden meaning from the text successfully. It was followed by Item 40 with a medium mean score of 3.14 , which indicates that 38.916 percent of the respondents are undecided about being strategic readers in the English language. It also shows students' self-efficiency in reading comprehension. The next high-rated was Item 34 with a mean score of 3.12, which shows that 46.798 percent of the respondents are firmly undecided about a belief that students should be given more time for group discussion and students' activities rather than teacher dominating the class.

The least-rated item under this construct was Item 33 with a medium mean score of 2.94, which indicates that 32.512 percent of the respondents disagreed with the statement that says: "Students should read other relevant materials (like magazines, books, articles) to understand the content (extensive reading)".

\section{Research Question two}

This section reports and discusses the results obtained from the data analysis for Research Question 2:

Is there a significant correlation between Saudi EFL students' foundational knowledge of English reading comprehension strategies and their beliefs about reading comprehension strategies?

In addition to descriptive statistics, an independent Pearson correlation test was also conducted to examine if there is a significant correlation between the students' foundational knowledge of English reading comprehension and their general beliefs about reading strategies. According to Creswell and Plano (2012), researchers using quantitative studies use correlation to see the relationship or association between research variables. This study utilized Cohen's (1988) Coefficient $r$, effect size, which postulates a small degree of association between the variables. There is a positive correlation when the value of $r$ is between the ranges of one to three. While it indicates a strong negative correlation when the value of $r$ is between -.one and -. three. It shows a medium degree of association between the variables if the value of $r$ is between the ranges of three to five, which indicates a positive correlation. It postulates that there is a negative correlation when the value of $r$ is between the ranges of three and five. Finally, it reveals a positive correlation when the value of $r$ is between the ranges of .5 to 1.0 , while it shows that there is a negative correlation when the value of $r$ is between the ranges of -.5 to -1.0 . Due to the 
non-normal distribution found in the data, the study proceeds with a non-parametric correlation suggested by Ary, Jacobs, Irvine, and Walker (2018).

Table 7. Correlation between Saudi EFL students' foundational knowledge of English reading strategies (SFRST) and the students' beliefs on reading strategies (SBRS)

\begin{tabular}{|c|c|c|c|}
\hline \multicolumn{4}{|c|}{ Spearman's Rho Correlation } \\
\hline \multirow{2}{*}{ SFRST } & \multicolumn{2}{|c|}{ SFRST } & SBRS \\
\hline & $\begin{array}{l}\text { Correlation } \\
\text { Coefficient }\end{array}$ & 1.000 & $3.382 * *$ \\
\hline & Sig. (2-tailed) & & .000 \\
\hline SBRS & $\mathrm{N}$ & 203 & 203 \\
\hline & $\begin{array}{l}\text { Correlation } \\
\text { Coefficient }\end{array}$ & $.382^{* *}$ & 1.000 \\
\hline & Sig. (2-tailed) & .000 & 203 \\
\hline
\end{tabular}

**Correlation is Significant at 0.01 (2-tailed)

Table seven shows the value of Spearson's correlation coefficient between Saudi EFL students' foundational knowledge of English reading strategies (SFRST) and their beliefs on reading strategies (SBRS). The value of Spearson's correlation coefficient $(r=.382)$ indicates that there is a medium positive correlation between Saudi EFL students' foundational knowledge of English reading strategies (SFRST) and their beliefs on reading strategies (SBRS). The $p$ value (2-tailed) indicated a significant correlation $(p=0.00)$ between these two constructs.

Moreover, the medium degree of association between these two variables indicates a positive medium correlation between the students' knowledge of reading and their beliefs about reading strategies. However, it also shows a need for the students to adjust their attitudes and perceptions towards reading strategies and their foundational knowledge of reading comprehension.

\section{Discussion}

The overall discussion of the results indicated that the students have a good foundational knowledge in most of the reading strategies of three phases: pre-reading, while-reading, and post-reading. The study found consistency in the students' use of collaboration in their foundational reading strategies (pre-reading, while reading, and post-reading). The results also support Horiba and Fukaya's (2015) study, which found that EFL learners need foundational knowledge of reading strategies to reach the optimal reading comprehension level. In addition to that, Okasha's (2020) findings of the study showed that the Saudi EFL learners need an innovative strategy to improve their reading. This study recommends that teachers to adopt new techniques of providing feedback to EFL learners, such as peer-review, reading conferences, and self-correction.

In the present study, the participants acknowledged the importance of pre-reading strategies in reading comprehension, and they claimed they are using those strategies in their English reading course. The finding was inconsistent with studies of Haryanto et al. (2016) and Torres (2017). The results show that the students are aware of the importance of using 
background knowledge before reading. Developing background knowledge is one of the significant roles of pre-reading activities/strategies. Brainstorming is also part of activities that utilize background knowledge (Crossley \& McNamara, 2016). Like Alenizi (2019) and Han and Choi (2018), the current study elaborated on the significant roles of culture and contextual knowledge in reading comprehension.

In this study, the students are familiar with collaborative learning in both school and home. The finding conformed with Horiba and Fukaya's (2015) study, which revealed that students' collaboration is one of the reading techniques that help the students to comprehend the meaning of the text. This result was inconsistent with the Rajab and Al-Sadi's (2015) study, which found students lack interest and motivation in academic reading.

On the other hand, the results indicated that the students need to improve their reading skills knowledge in some areas of the three phases of reading strategies such as: extensive reading, and reading between the lines. Another area is improving extensive reading strategies which engage in reading other relevant materials to understand the content. Finally, appropriate use of reading strategies is required for students to perform specific language tasks more effectively.

The result has also shown a positive medium correlation between the students' foundational knowledge of reading, and their beliefs about reading strategies. This finding was consistent with Shehzad, Lashari, Lashari, and Hasan's (2020) study, which indicated reading self-efficacy beliefs are positively and substantially associated with reading strategies. The finding of this study is closed to studies of Ahmadian and Pasand (2017) and Kim (2016). Ahmadian and Pasand's (2017) study showed a substantially positive relationship between the perceived usage of metacognitive online reading strategies by learners and their self-efficacy in understanding reading. While, Kim's (2016) study revealed that metacognitive strategy usage was described as having an important relationship with reading skills concerning the use of reading strategy. On the other hand, the results contrasted Taladngoen et al. (2020) findings which showed that linguistic knowledge impacted on their reading comprehension ability than their perceptions.

\section{Conclusion}

In summary, reading comprehension is part of the four basic language skills (reading, writing, listening, and speaking). Saudi Ministry of Higher Education prioritized foundational program made it mandatory for any student before joining a degree programme at universities and colleges. As observed, most of the previous studies conducted in the foreign language contexts about learning English reading and other foundational skills have focused on measuring reading strategies and the students' performances in reading comprehension.

Therefore, this current descriptive study focuses on the foundational reading knowledge of EFL learners. It described the students' foundational knowledge of reading strategies (prereading strategies, while-reading strategies, and post-reading strategies). It also examined the students' beliefs about reading strategies. The overall results found students have an excellent foundational knowledge of reading strategies. However, some areas that need to be improved further by the students. Furthermore, the correlational test has shown a significant medium 
correlation between the students' foundational knowledge of reading strategies and their beliefs about reading strategies. This study suggests a need to improve students' knowledge of extensive reading, reading between the lines, and using more of a learner-centered approach to help students become more strategic readers.

\section{About the Author:}

Dr. Saud Alenezi is an assistant professor at NBU. He is teaching English courses at the languages and translation department. His research interests include second language learning, Applied Linguistics, practices in the teaching of foreign languages, Language Assessment, Language motivation.. ORCiD: https://orcid.org/0000-0003-3848-7363

\section{References}

Ahmadian, M., \& Pasand, P. G. (2017). EFL learners' use of online metacognitive reading strategies and its relation to their self-efficacy in reading. The reading matrix: an international online journal, 17(2), 117-132.

Al-Mahrooqi, R., \& Denman, C. (2016). Establishing a reading culture in Arabic and English in Oman. Arab World English Journal (AWEJ), 7(1), 5-17. DOI: 10.24093/awej/vol7no1.1

Al-Qahtani, A. (2016). Why Do Saudi EFL readers exhibit poor reading abilities? English Language and Literature Studies, 6(1), 1-15. https://doi.org/10.5539/ells.v6n1p1

Al-Jahwari, Y., \& Al-Humaidi, S. (2015). Prior knowledge in EFL reading comprehension: Omani teachers' perspectives \& classroom strategies. International Journal of Applied Linguistics and English Literature, 4(1), 169-181.

Alshumaimeri, Y. (2017). The effects of reading method on the comprehension performance of Saudi EFL students. International Electronic Journal of Elementary Education, 4(1), 185-195

Alenizi, M. A. K. (2019) Understanding of reading among teachers and learners: A descriptive study of pre-university English language teaching /learning in Saudi Arabia. Arab World English Journal, 10(2)293-306. https://dx.doi.org/10.24093/awej/vol10no2.23

Al Asmari, A., \& Javid, C. Z. (2018). Role of content schema in reading comprehension among Saudi EFL students: EFL teachers' perspective and use of appropriate classroom strategies. International Journal of English Linguistics, 8(4), 96-105. DOI: 10.5539/ijel.v8n4p96

Ary, D., Jacobs, L. C., Irvine, C. K. S., \& Walker, D. (2018). Introduction to research in education. Boston, USA, Cengage Learning.

Bakhshalinezhad, L., Nikou, F. R., \& Bonyadi, A. (2015). Using the think-aloud technique for determining different reading strategies used by Iranian EFL learners. Advances in Language and Literary Studies, 6(3), 15-22.

Chomsky, N. (1986). Knowledge of language: Its nature, origin, and use. California, USA, Greenwood Publishing Group.

Cohen. J. (1988). Statistical power analysis for the behavioral sciences ( $2^{\text {nd }}$ ed.). New York: Routledge

Crossley, S. A., Kyle, K., \& McNamara, D. S. (2016). The tool for the automatic analysis of text cohesion (TAACO): Automatic assessment of local, global, and text cohesion. Behavior research methods, 48(4), 1227-1237.

Creswell, J.W., \& Plano, C. (2012). Designing and conducting mixed method research, ( $2^{\text {nd }}$ ed.). Thousand Oaks, CA SAGE.

Ehri, L. (1991). Development of the ability to read words. In R. Barr, M. Kamil, P. Mosenthal, \& P. Pearson (Eds.), Handbook of reading research (Vol. II, pp. 383-417). London: Longman.

Fitrisia, D., Tan, K. E., \& Yusuf, Y. Q. (2015). Investigating metacognitive awareness of reading strategies to strengthen students' performance in reading comprehension. Asia Pacific Journal of Educators and Education, 30, 15-30. 
Haryanto, E., Mukminin, A., Habibi, A., Sulistiyo, U., \& Peni, M. S. (2016). English reading Comprehension Strategies Employed by the students of first-year English education program. In Ninth International Conference on Applied Linguistics (CONAPLIN 9). Atlantis Press. https://doi.org/10.2991/conaplin-16.2017.19

Han, S. Y., \& Choi, Y. H. (2018). Post-reading question-generation activities and cooperative learning in EFL reading. English Teaching, 73(2), 37-58. DOI: 10.15858/engtea.73.2.201806.37

Habók, A., \& Magyar, A. (2018). Validation of a self-regulated foreign language learning strategy questionnaire through multidimensional modelling. Frontiers in psychology, 9. DOI:10.3389/fpsyg.2018.01388

Horiba, Y., \& Fukaya, K. (2015). Reading and learning from L2 text: Effects of reading goal, topic familiarity, and language proficiency. Reading in a Foreign Language, 27(1), 22-46.

Hudson, T. (2007). Teaching second language reading. Oxford: Oxford University Press.

Krashen, S., \& Brown, C.L. (2007). What is academic language proficiency? STETS Language and Communication Review, 6(1), 1-4. DOI: 10.5054/tj.2011.274624

Kim, H. (2016). The relationships between Korean university students' reading attitude, reading strategy use, and reading proficiency. Reading Psychology, 37(8), 1162-1195. https://doi.org/10.1080/02702711.2016.1193581

Mitchell, B., \& Alfuraih, A. (2017). English language teaching in the Kingdom of Saudi Arabia: Past, present and beyond. Mediterranean Journal of Social Sciences, 8(2), 317-317. DOI: 10.5901/mjss.2017.v8n2p317

Nezami, S. (2012). A critical study of comprehension strategies and general problems in reading skill faced by Arab EFL learners with special reference to Najran University in Saudi Arabia. International Journal of Social Sciences and Education, 2(3), 306-316.

Piaget, J. (1976). Piaget's theory. In Inhelder B., Chipman H.H., Zwingmann C. (eds). Piaget and his school (pp. 11-23). Springer, Berlin, Heidelberg.

Qrqez, M., \& Ab Rashid, R. (2017). Reading comprehension difficulties among EFL learners: The case of first and second year students at Yarmouk University in Jordan. Arab World English Journal (AWEJ) 8(3), 421-431. https://dx.doi.org/10.24093/awej/vol8no3.27

Okasha, M. A. (2020). Using strategic reading techniques for Improving EFL reading skills. Arab World English Journal, 11(2), 311-322. DOI: 10.24093/awej/vol11no2.22

Rajab, H., \& Al-Sadi, A. (2015). An empirical study of reading habits and interests of Saudi University EFL learners. International Journal of Linguistics, 7(2), 1-17. DOI: 10.5296/ijl.v7i2.7034

Shehzad, M. W., Anwar Lashari, T., Anwar Lashari, S., \& Hasan, M. K. (2020). The interplay of self-efficacy sources and reading self-efficacy beliefs in metacognitive reading strategies. International Journal of Instruction, 13(4), 523-544. nal of Instruction, 13(4), 523-544. DOI: 10.29333/iji.2020.13433a

Shoebottom, P. (2015). The importance of reading. Retrieved from http://esl.fis.edu/parents/ advice/read.htm

Taladngoen, U., Palawatwichai, N., Estaban, R. H., \& Phuphawan, N. (2020). A study of factors affecting EFL tertiary students' reading comprehension ability. Rangsit Journal of Educational Studies, 7(1), 12-21.

Torres, D. B. (2017). Effectiveness and students' perception of the use of pre-reading strategies and summaries: A case study of adult EFL Students in a reading comprehension Course. Revista de Lenguas Modernas, (27), 285-310.

Vygotsky, L. S. (1978). Mind in society: The development of higher psychological processes. Cambridge, USA: Harvard University Press.

Wang, Q. (2017). English reading instruction under the background of core competencies: Problems, principles, goals and pathways. English Language Learning, 2, 19-23. 
Appendix A

Table 3. Students' foundational knowledge of pre-reading strategies

\begin{tabular}{|c|c|c|c|c|c|c|c|c|c|}
\hline $\mathrm{N}$ & Statements & $\mathrm{F}$ & Always & Often & Sometimes & Rarely & Never & Mean & SD \\
\hline 1 & $\begin{array}{l}\text { Planning what to do } \\
\text { before reading the text. }\end{array}$ & $\begin{array}{l}\mathrm{N} \\
\%\end{array}$ & $\begin{array}{c}23 \\
11.3\end{array}$ & $\begin{array}{c}98 \\
48.3 \\
\end{array}$ & $\begin{array}{c}59 \\
29.1\end{array}$ & $\begin{array}{l}19 \\
9.3\end{array}$ & $\begin{array}{c}4 \\
2.0\end{array}$ & 3.58 & 0.883 \\
\hline 2 & $\begin{array}{l}\text { Paying attention to the } \\
\text { titles and subtitles }\end{array}$ & $\begin{array}{l}\mathrm{N} \\
\%\end{array}$ & $\begin{array}{c}57 \\
28.08\end{array}$ & $\begin{array}{c}111 \\
54.68\end{array}$ & $\begin{array}{c}30 \\
14.78\end{array}$ & $\begin{array}{c}5 \\
2.46\end{array}$ & $\begin{array}{l}0 \\
-\end{array}$ & 4.08 & 0.723 \\
\hline 3 & $\begin{array}{l}\text { Focusing on the } \\
\text { keywords from the } \\
\text { title. }\end{array}$ & $\begin{array}{l}\mathrm{N} \\
\%\end{array}$ & $\begin{array}{c}24 \\
11.82\end{array}$ & $\begin{array}{c}86 \\
42.36\end{array}$ & $\begin{array}{c}75 \\
36.95\end{array}$ & $\begin{array}{c}17 \\
8.38\end{array}$ & $\begin{array}{c}1 \\
0.49\end{array}$ & 3.57 & 0.826 \\
\hline 4 & $\begin{array}{l}\text { I am brainstorming the } \\
\text { possible topics } \\
\text { addressed in the text. }\end{array}$ & $\begin{array}{l}\mathrm{N} \\
\%\end{array}$ & $\begin{array}{c}34 \\
16.75\end{array}$ & $\begin{array}{c}74 \\
36.45\end{array}$ & $\begin{array}{c}40 \\
19.70\end{array}$ & $\begin{array}{c}47 \\
23.15\end{array}$ & $\begin{array}{c}8 \\
3.95\end{array}$ & 3.39 & 1.131 \\
\hline 5 & $\begin{array}{l}\text { I am making } \\
\text { predictions about the } \\
\text { possible content of the } \\
\text { text in a general way. }\end{array}$ & $\begin{array}{l}\mathrm{N} \\
\%\end{array}$ & $\begin{array}{c}80 \\
39.41\end{array}$ & $\begin{array}{c}100 \\
49.26\end{array}$ & $\begin{array}{c}16 \\
7.88\end{array}$ & $\begin{array}{c}6 \\
2.95\end{array}$ & $\begin{array}{c}1 \\
0.50\end{array}$ & 4.24 & 0.762 \\
\hline 6 & $\begin{array}{l}\text { I am checking if the } \\
\text { predictions about the } \\
\text { text are correct or not. }\end{array}$ & $\begin{array}{l}\mathrm{N} \\
\%\end{array}$ & $\begin{array}{c}42 \\
20.69\end{array}$ & $\begin{array}{c}26 \\
12.81\end{array}$ & $\begin{array}{c}112 \\
55.17\end{array}$ & $\begin{array}{c}15 \\
7.39\end{array}$ & $\begin{array}{c}8 \\
3.94\end{array}$ & 3.39 & 1.020 \\
\hline 7 & $\begin{array}{l}\text { Predicting the content } \\
\text { from the pictures. }\end{array}$ & $\begin{array}{l}\mathrm{N} \\
\%\end{array}$ & $\begin{array}{c}16 \\
7.88\end{array}$ & $\begin{array}{c}82 \\
40.39 \\
\end{array}$ & $\begin{array}{c}57 \\
28.08\end{array}$ & $\begin{array}{c}35 \\
17.24\end{array}$ & $\begin{array}{c}13 \\
6.41\end{array}$ & 3.26 & 1.042 \\
\hline 8 & $\begin{array}{l}\text { Watching videos about } \\
\text { the topic of the text to } \\
\text { activate schema. }\end{array}$ & $\begin{array}{l}\mathrm{N} \\
\%\end{array}$ & $\begin{array}{c}47 \\
23.15\end{array}$ & $\begin{array}{c}79 \\
38.92\end{array}$ & $\begin{array}{c}62 \\
30.54\end{array}$ & $\begin{array}{c}13 \\
6.40\end{array}$ & $\begin{array}{c}2 \\
0.99\end{array}$ & 3.77 & 0.912 \\
\hline 9 & $\begin{array}{l}\text { Thinking about the } \\
\text { possible vocabulary } \\
\text { that could be } \\
\text { encountered in the text. }\end{array}$ & $\begin{array}{l}\mathrm{N} \\
\%\end{array}$ & $\begin{array}{c}100 \\
49.26\end{array}$ & $\begin{array}{c}90 \\
44.33\end{array}$ & $\begin{array}{c}13 \\
6.41\end{array}$ & $\begin{array}{c}11 \\
5.42\end{array}$ & $\begin{array}{c}4 \\
1.97\end{array}$ & 3.84 & 0.787 \\
\hline 10 & $\begin{array}{l}\text { Talking with other } \\
\text { coursemates about }\end{array}$ & $\begin{array}{l}\mathrm{N} \\
\%\end{array}$ & & & & $\begin{array}{l}0 \\
-\end{array}$ & $\begin{array}{l}0 \\
-\end{array}$ & 4.43 & 0.612 \\
\hline & & & & & & & & & \\
\hline
\end{tabular}

Level of indicator: Very low $=1.00-1.49$, Low $=1.50-2.49$, Medium $=2.50-3.49$, High $=3.50-4.49$, Very high $=$ 4.50-5.00

Appendix B

Table 4. Students' foundational knowledge of "while reading" strategies

\begin{tabular}{|c|c|c|c|c|c|c|c|c|c|}
\hline $\mathrm{N}$ & Statements & $\mathrm{F}$ & Always & Often & Sometimes & Rarely & Never & Mean & SD \\
\hline 11 & $\begin{array}{l}\text { Understanding the } \\
\text { topic sentence in a } \\
\text { paragraph. }\end{array}$ & $\begin{array}{l}\mathrm{N} \\
\%\end{array}$ & $\begin{array}{c}45 \\
22.167\end{array}$ & $\begin{array}{c}114 \\
56.158\end{array}$ & $\begin{array}{c}33 \\
16.256\end{array}$ & $\begin{array}{c}10 \\
4.926\end{array}$ & $\begin{array}{c}1 \\
0.493\end{array}$ & 3.95 & 0.791 \\
\hline 12 & $\begin{array}{l}\text { Paying attention to } \\
\text { punctuations. }\end{array}$ & $\begin{array}{l}\mathrm{N} \\
\%\end{array}$ & $\begin{array}{c}18 \\
8.867\end{array}$ & $\begin{array}{c}78 \\
38.424\end{array}$ & $\begin{array}{c}62 \\
30.542\end{array}$ & $\begin{array}{c}37 \\
18.227\end{array}$ & $\begin{array}{c}8 \\
3.941\end{array}$ & 3.30 & 0.997 \\
\hline 13 & $\begin{array}{l}\text { Paying attention to the } \\
\text { type of text when } \\
\text { reading (like narrative, } \\
\text { expository, scientific } \\
\text { or } \\
\text { reference, etc.) }\end{array}$ & $\begin{array}{l}\mathrm{N} \\
\%\end{array}$ & $\begin{array}{c}55 \\
27.094\end{array}$ & $\begin{array}{c}118 \\
58.128\end{array}$ & $\begin{array}{c}24 \\
11.823\end{array}$ & $\begin{array}{c}6 \\
2.956\end{array}$ & $\begin{array}{l}0 \\
-\end{array}$ & 4.09 & 0.708 \\
\hline 14 & $\begin{array}{l}\text { Guessing the meaning } \\
\text { of unknown words } \\
\text { from the text. }\end{array}$ & $\begin{array}{l}\mathrm{N} \\
\%\end{array}$ & $\begin{array}{c}31 \\
15.271\end{array}$ & $\begin{array}{c}84 \\
41.379\end{array}$ & $\begin{array}{c}61 \\
30.049\end{array}$ & $\begin{array}{c}24 \\
11.823\end{array}$ & $\begin{array}{c}3 \\
1.478\end{array}$ & 3.57 & 0.938 \\
\hline
\end{tabular}


Arab World English Journal (AWEJ) Volume 12. Number 1. March 2021

Investigating Saudi EFL Students' Knowledge and Beliefs

Alenezi

\begin{tabular}{|c|c|c|c|c|c|c|c|c|c|}
\hline 15 & $\begin{array}{l}\text { Skipping unknown } \\
\text { words while reading. }\end{array}$ & $\begin{array}{l}\mathrm{N} \\
\%\end{array}$ & $\begin{array}{c}68 \\
33.498 \\
\end{array}$ & $\begin{array}{c}107 \\
52.709 \\
\end{array}$ & $\begin{array}{c}26 \\
12.808 \\
\end{array}$ & $\begin{array}{c}2 \\
0.985 \\
\end{array}$ & $\begin{array}{l}0 \\
- \\
\end{array}$ & 4.19 & 0.685 \\
\hline 16 & $\begin{array}{l}\text { Stopping to check the } \\
\text { meaning of unknown } \\
\text { words. }\end{array}$ & $\begin{array}{l}\mathrm{N} \\
\%\end{array}$ & $\begin{array}{c}24 \\
11.823\end{array}$ & $\begin{array}{c}15 \\
7.389\end{array}$ & $\begin{array}{c}82 \\
40.394\end{array}$ & $\begin{array}{c}56 \\
27.586\end{array}$ & $\begin{array}{c}26 \\
12.808\end{array}$ & 2.78 & 1.137 \\
\hline 17 & $\begin{array}{l}\text { Using dictionary or } \\
\text { google translator to } \\
\text { find the meaning of } \\
\text { unknown words. }\end{array}$ & $\begin{array}{l}\mathrm{N} \\
\%\end{array}$ & $\begin{array}{c}124 \\
61.084\end{array}$ & $\begin{array}{c}70 \\
34.483\end{array}$ & $\begin{array}{c}6 \\
2.956\end{array}$ & $\begin{array}{c}3 \\
1.478\end{array}$ & $\begin{array}{l}0 \\
-\end{array}$ & 4.55 & 0.630 \\
\hline 18 & $\begin{array}{l}\text { Using English } \\
\text { Grammar knowledge } \\
\text { to help in } \\
\text { understanding the text. }\end{array}$ & $\begin{array}{l}\mathrm{N} \\
\%\end{array}$ & $\begin{array}{c}81 \\
39.901\end{array}$ & $\begin{array}{c}104 \\
51.232\end{array}$ & $\begin{array}{c}14 \\
6.897\end{array}$ & $\begin{array}{c}4 \\
1.970\end{array}$ & $\begin{array}{l}0 \\
-\end{array}$ & 4.29 & 0.682 \\
\hline 19 & $\begin{array}{l}\text { Skim the text quickly } \\
\text { to understanding the } \\
\text { main idea }\end{array}$ & $\begin{array}{l}\mathrm{N} \\
\%\end{array}$ & $\begin{array}{c}27 \\
13.300\end{array}$ & $\begin{array}{c}156 \\
76.847\end{array}$ & $\begin{array}{c}20 \\
9.853\end{array}$ & $\begin{array}{l}0 \\
-\end{array}$ & $\begin{array}{l}0 \\
-\end{array}$ & 4.03 & 0.481 \\
\hline 20 & $\begin{array}{l}\text { Scan the text to } \\
\text { understand the } \\
\text { specific idea in the } \\
\text { text. }\end{array}$ & $\begin{array}{l}\mathrm{N} \\
\%\end{array}$ & $\begin{array}{c}95 \\
46.798\end{array}$ & $\begin{array}{c}87 \\
46.798\end{array}$ & $\begin{array}{c}21 \\
10.345\end{array}$ & $\begin{array}{l}0 \\
-\end{array}$ & $\begin{array}{l}0 \\
-\end{array}$ & 4.36 & 0.664 \\
\hline
\end{tabular}

Level of indicator: Very low $=1.00-1.49$, Low $=1.50-2.49$, Medium $=2.50-3.49$, High $=3.50-4.49$, Very high $=$ $4.50-5.00$

Appendix C

Table 5. Students' foundational knowledge of post-reading strategies

\begin{tabular}{|c|c|c|c|c|c|c|c|c|c|}
\hline $\mathrm{N}$ & Statements & $\mathrm{F}$ & Always & Often & Sometimes & Rarely & Never & Mean & SD \\
\hline 21 & $\begin{array}{l}\text { Re-read the text } \\
\text { more than one time } \\
\text { if not getting the } \\
\text { main idea. }\end{array}$ & $\begin{array}{l}\mathrm{N} \\
\%\end{array}$ & $\begin{array}{c}36 \\
31.034\end{array}$ & $\begin{array}{c}113 \\
55.665\end{array}$ & $\begin{array}{c}23 \\
11.330\end{array}$ & $\begin{array}{c}3 \\
1.478\end{array}$ & $\begin{array}{c}1 \\
0.493\end{array}$ & 4.15 & 0.712 \\
\hline 22 & $\begin{array}{l}\text { Making notes for the } \\
\text { main points in the } \\
\text { text. }\end{array}$ & $\begin{array}{l}\mathrm{N} \\
\%\end{array}$ & $\begin{array}{c}34 \\
16.749\end{array}$ & $\begin{array}{c}82 \\
40.394\end{array}$ & $\begin{array}{c}57 \\
28.079\end{array}$ & $\begin{array}{c}26 \\
12.808\end{array}$ & $\begin{array}{c}4 \\
1.970\end{array}$ & 3.57 & 0.979 \\
\hline 23 & $\begin{array}{l}\text { Evaluate the plan to } \\
\text { check whether I } \\
\text { achieve my purpose } \\
\text { of reading or not. }\end{array}$ & $\begin{array}{l}\mathrm{N} \\
\%\end{array}$ & $\begin{array}{c}40 \\
19.704\end{array}$ & $\begin{array}{c}124 \\
61.084\end{array}$ & $\begin{array}{c}30 \\
14.778\end{array}$ & $\begin{array}{c}9 \\
4.434\end{array}$ & $\begin{array}{l}0 \\
-\end{array}$ & 3.96 & 0.723 \\
\hline 24 & $\begin{array}{l}\text { Giving the correct } \\
\text { answer to the } \\
\text { reading } \\
\text { comprehension } \\
\text { questions. }\end{array}$ & $\begin{array}{l}\mathrm{N} \\
\%\end{array}$ & $\begin{array}{c}79 \\
38.916\end{array}$ & $\begin{array}{c}115 \\
56.650\end{array}$ & $\begin{array}{c}9 \\
4.433\end{array}$ & $\begin{array}{l}0 \\
-\end{array}$ & $\begin{array}{l}0 \\
-\end{array}$ & 4.34 & 0.562 \\
\hline 25 & $\begin{array}{l}\text { Summarizing the } \\
\text { text in one's own } \\
\text { words. }\end{array}$ & $\begin{array}{l}\mathrm{N} \\
\%\end{array}$ & $\begin{array}{c}24 \\
11.823\end{array}$ & $\begin{array}{c}77 \\
37.931\end{array}$ & $\begin{array}{c}79 \\
38.916\end{array}$ & $\begin{array}{c}19 \\
9.360\end{array}$ & $\begin{array}{c}4 \\
1.970\end{array}$ & 3.48 & 0.892 \\
\hline 26 & $\begin{array}{l}\text { Making inferences } \\
\text { from the text to } \\
\text { understand the } \\
\text { hidden meaning. }\end{array}$ & $\begin{array}{l}\mathrm{N} \\
\%\end{array}$ & $\begin{array}{c}16 \\
7.882\end{array}$ & $\begin{array}{c}35 \\
17.241\end{array}$ & $\begin{array}{c}114 \\
56.158\end{array}$ & $\begin{array}{c}31 \\
15.271\end{array}$ & $\begin{array}{c}7 \\
3.448\end{array}$ & 3.11 & 0.878 \\
\hline 27 & $\begin{array}{l}\text { Discussing with } \\
\text { other coursemates } \\
\text { about the text. }\end{array}$ & $\begin{array}{l}\mathrm{N} \\
\%\end{array}$ & $\begin{array}{c}119 \\
58.620\end{array}$ & $\begin{array}{c}78 \\
38.424\end{array}$ & $\begin{array}{c}6 \\
2.956\end{array}$ & $\begin{array}{l}0 \\
-\end{array}$ & $\begin{array}{l}0 \\
-\end{array}$ & 4.56 & 0.554 \\
\hline 28 & $\begin{array}{l}\text { Discussing the topic } \\
\text { with others (such as } \\
\text { tutors, brothers, }\end{array}$ & $\begin{array}{l}\mathrm{N} \\
\%\end{array}$ & $\begin{array}{c}71 \\
34.975\end{array}$ & $\begin{array}{c}73 \\
35.961\end{array}$ & $\begin{array}{c}42 \\
20.690\end{array}$ & $\begin{array}{c}13 \\
6.404\end{array}$ & $\begin{array}{c}4 \\
1.970\end{array}$ & 3.96 & 0.997 \\
\hline
\end{tabular}


Arab World English Journal (AWEJ) Volume 12. Number 1. March 2021

Investigating Saudi EFL Students' Knowledge and Beliefs

Alenezi

\begin{tabular}{|c|c|c|c|c|c|c|c|c|c|}
\hline & $\begin{array}{l}\text { sisters or parents) at } \\
\text { home. }\end{array}$ & & & & & & & & \\
\hline 29 & $\begin{array}{l}\text { Understanding the } \\
\text { whole text alone } \\
\text { (means that you can } \\
\text { read and } \\
\text { comprehend a text } \\
\text { while reading alone, } \\
\text { without peer } \\
\text { collaboration or } \\
\text { teachers' } \\
\text { explanation). }\end{array}$ & $\begin{array}{l}\mathrm{N} \\
\%\end{array}$ & $\begin{array}{c}2 \\
0.985\end{array}$ & $\begin{array}{c}130 \\
64.039\end{array}$ & $\begin{array}{c}55 \\
27.094\end{array}$ & $\begin{array}{c}15 \\
7.389\end{array}$ & $\begin{array}{c}1 \\
0.493\end{array}$ & 3.58 & 0.666 \\
\hline 30 & $\begin{array}{l}\text { Reading other } \\
\text { materials (books, } \\
\text { articles etc.) related } \\
\text { to the text to help in } \\
\text { understanding the } \\
\text { text. }\end{array}$ & $\begin{array}{l}\mathrm{N} \\
\%\end{array}$ & $\begin{array}{c}3 \\
1.478\end{array}$ & $\begin{array}{c}31 \\
15.271\end{array}$ & $\begin{array}{c}71 \\
34.975\end{array}$ & $\begin{array}{c}76 \\
37.438\end{array}$ & $\begin{array}{c}22 \\
10.837\end{array}$ & 2.59 & 0.926 \\
\hline
\end{tabular}

Level of indicator: Very low $=1.00-1.49$, Low $=1.50-2.49$, Medium $=2.50-3.49$, High $=3.50-4.49$, Very high $=$ $4.50-5.00$

Appendix D

Table 6. Students' beliefs about English reading strategies

\begin{tabular}{|c|c|c|c|c|c|c|c|c|c|}
\hline $\mathrm{N}$ & Statements & $\mathrm{F}$ & SA & $\mathrm{A}$ & $\mathrm{U}$ & $\mathrm{D}$ & SD & Mean & SD \\
\hline 31 & $\begin{array}{l}\text { Language learning } \\
\text { involves culture, so it } \\
\text { is important to } \\
\text { increase Saudi } \\
\text { learners' cultural } \\
\text { awareness of English } \\
\text { speakers. }\end{array}$ & $\begin{array}{l}\mathrm{N} \\
\%\end{array}$ & $\begin{array}{c}131 \\
64.532\end{array}$ & $\begin{array}{c}71 \\
34.975\end{array}$ & $\begin{array}{c}1 \\
0.494\end{array}$ & $\begin{array}{l}0 \\
-\end{array}$ & $\begin{array}{l}0 \\
-\end{array}$ & 4.64 & 0.491 \\
\hline 32 & $\begin{array}{l}\text { Students should read } \\
\text { other relevant } \\
\text { materials at } \\
\text { home/library the class } \\
\text { to comprehensive. } \\
\text { (Extensive reading). }\end{array}$ & $\begin{array}{l}\mathrm{N} \\
\%\end{array}$ & $\begin{array}{c}73 \\
35.960\end{array}$ & $\begin{array}{c}92 \\
45.320\end{array}$ & $\begin{array}{c}32 \\
15.764\end{array}$ & $\begin{array}{c}3 \\
1.478\end{array}$ & $\begin{array}{c}3 \\
1.478\end{array}$ & 4.13 & 0.834 \\
\hline 33 & $\begin{array}{l}\text { Students should read } \\
\text { other relevant } \\
\text { materials (like } \\
\text { magazines, books, } \\
\text { articles) to } \\
\text { understand the } \\
\text { content (extensive } \\
\text { reading). }\end{array}$ & $\begin{array}{l}\mathrm{N} \\
\%\end{array}$ & $\begin{array}{c}5 \\
2.464\end{array}$ & $\begin{array}{c}61 \\
30.049\end{array}$ & $\begin{array}{c}62 \\
30.542\end{array}$ & $\begin{array}{c}66 \\
32.512\end{array}$ & $\begin{array}{c}9 \\
4.433\end{array}$ & 2.94 & 0.950 \\
\hline 34 & $\begin{array}{l}\text { In English reading } \\
\text { classes, students } \\
\text { should be given more } \\
\text { time for group } \\
\text { discussion and } \\
\text { students' activities } \\
\text { rather than the }\end{array}$ & $\begin{array}{l}\mathrm{N} \\
\%\end{array}$ & $\begin{array}{c}12 \\
5.912\end{array}$ & $\begin{array}{c}49 \\
24.138\end{array}$ & $\begin{array}{c}95 \\
46.798\end{array}$ & $\begin{array}{c}45 \\
22.167\end{array}$ & $\begin{array}{c}2 \\
0.985\end{array}$ & 3.12 & 0.854 \\
\hline
\end{tabular}


Arab World English Journal (AWEJ) Volume 12. Number 1. March 2021

Investigating Saudi EFL Students' Knowledge and Beliefs

Alenezi

\begin{tabular}{|c|c|c|c|c|c|c|c|c|c|}
\hline & $\begin{array}{l}\text { teacher dominating } \\
\text { the class. }\end{array}$ & & & & & & & & \\
\hline 35 & $\begin{array}{l}\text { English reading } \\
\text { classes should } \\
\text { emphasize on } \\
\text { students' ability to } \\
\text { guess meaning of } \\
\text { unknown words from } \\
\text { the context. }\end{array}$ & $\begin{array}{l}\mathrm{N} \\
\%\end{array}$ & $\begin{array}{c}107 \\
52.709\end{array}$ & $\begin{array}{c}78 \\
38.424\end{array}$ & $\begin{array}{c}15 \\
7.389\end{array}$ & $\begin{array}{c}2 \\
0.985\end{array}$ & $\begin{array}{c}1 \\
0.493\end{array}$ & 4.42 & 0.715 \\
\hline 36 & $\begin{array}{l}\text { I can use reading } \\
\text { between the lines } \\
\text { technique to find } \\
\text { hidden meaning from } \\
\text { the text successfully. }\end{array}$ & $\begin{array}{l}\mathrm{N} \\
\%\end{array}$ & $\begin{array}{c}15 \\
7.389\end{array}$ & $\begin{array}{c}59 \\
29.064\end{array}$ & $\begin{array}{c}108 \\
53.202\end{array}$ & $\begin{array}{c}18 \\
8.867\end{array}$ & $\begin{array}{c}3 \\
1.478\end{array}$ & 3.32 & 0.797 \\
\hline 37 & $\begin{array}{l}\text { In English reading } \\
\text { classes the focus } \\
\text { should be more on } \\
\text { the meaning rather } \\
\text { than the rules of } \\
\text { grammar. }\end{array}$ & $\begin{array}{l}\mathrm{N} \\
\%\end{array}$ & $\begin{array}{c}124 \\
61.084\end{array}$ & $\begin{array}{c}71 \\
34.975\end{array}$ & $\begin{array}{c}7 \\
3.447\end{array}$ & $\begin{array}{c}1 \\
0.494\end{array}$ & $\begin{array}{l}0 \\
-\end{array}$ & 4.57 & 0.588 \\
\hline 38 & $\begin{array}{l}\text { Students need to read } \\
\text { intensively (intensive } \\
\text { reading strategy = } \\
\text { reading in detail with } \\
\text { a specific purpose to } \\
\text { reading tasks). }\end{array}$ & $\begin{array}{l}\mathrm{N} \\
\%\end{array}$ & $\begin{array}{c}110 \\
54.187\end{array}$ & $\begin{array}{c}87 \\
42.857\end{array}$ & $\begin{array}{c}5 \\
2.463\end{array}$ & $\begin{array}{c}1 \\
0.494\end{array}$ & $\begin{array}{l}0 \\
-\end{array}$ & 4.51 & 0.575 \\
\hline 39 & $\begin{array}{l}\text { I read other additional } \\
\text { English materials } \\
\text { such as newspapers, } \\
\text { magazines, and books } \\
\text { in addition to course } \\
\text { material. }\end{array}$ & $\begin{array}{l}\mathrm{N} \\
\%\end{array}$ & $\begin{array}{c}47 \\
23.153\end{array}$ & $\begin{array}{c}136 \\
66.995\end{array}$ & $\begin{array}{c}20 \\
9.852\end{array}$ & $\begin{array}{l}0 \\
-\end{array}$ & $\begin{array}{l}0 \\
\\
-\end{array}$ & 4.13 & 0.560 \\
\hline 40 & $\begin{array}{l}\text { I am a strategic and } \\
\text { effective reader in the } \\
\text { English language (= I } \\
\text { can successfully, use } \\
\text { varieties of strategies } \\
\text { to understand what I } \\
\text { read, before, during } \\
\text { and after reading). }\end{array}$ & $\begin{array}{l}\mathrm{N} \\
\%\end{array}$ & $\begin{array}{c}17 \\
8.374\end{array}$ & $\begin{array}{c}58 \\
28.571\end{array}$ & $\begin{array}{c}79 \\
38.916\end{array}$ & $\begin{array}{c}35 \\
17.241\end{array}$ & $\begin{array}{c}14 \\
6.898\end{array}$ & 3.14 & 1.027 \\
\hline
\end{tabular}

Level of indicator: Very low $=1.00-1.49$, Low $=1.50-2.49$, Medium $=2.50-3.49$, High $=3.50-4.49$, Very high $=$

$4.50-5.00$ 